\title{
Evaluation of a multiplex flow immunoassay versus conventional assays in detecting autoantibodies in systemic lupus erythematosus
}

\author{
Elaine YL Au *, WK Ip, CS Lau, YT Chan
}

\section{A B S T R A C T}

Introduction: Conventional diagnostic assays are being replaced with automated multiplex assays, but their performance needs to be evaluated. We compared a multiplex flow immunoassay with conventional techniques in the detection of antinuclear antibodies (ANAs) and antibodies to specific extractable nuclear antigens (ENAs) in serum samples from patients with systemic lupus erythematosus.

Methods: A total of 140 consecutive Chinese patients with systemic lupus erythematosus and 41 healthy controls were included. The automated BioPlex 2200 ANA Screen assay (Bio-Rad Laboratories, Hercules [CA], US) was compared with indirect immunofluorescence. In addition, use of BioPlex 2200 to detect anti-ENA antibodies was compared with in-house assays of countercurrent immunoelectrophoresis (CIEP), enzyme-linked immunosorbent assay (ELISA), and line blot.

Results: The sensitivity and specificity of BioPlex in detecting ANAs (91.4\% and 95.1\%, respectively) were comparable to those of indirect immunofluorescence (90.7\% and $85.4 \%$, respectively). Overall, BioPlex achieved the best agreement with ELISA in detecting

This article was published on 25 May 2018 at www.hkmj.org. anti-ENA antibodies: agreement was $>90 \%$ for most antibody types ( $\kappa=0.79-0.94)$. In contrast, agreement

was poorest with CIEP, ranging from $85.6 \%(\kappa=0.33)$ for anti-Sm antibodies to $93.9 \%(\kappa=0.88)$ for anti-Ro antibodies. Overall, BioPlex and ELISA had the highest sensitivity, whereas CIEP had the highest specificity. In terms of disease association, anti-Sm detected by CIEP had the best positive predictive value and specificity for lupus nephritis.

Conclusions: In a local lupus cohort, BioPlex showed comparable sensitivity to indirect immunofluorescence in detecting ANAs and comparable performance to ELISA in detecting anti-ENA antibodies. However, CIEP was the best method in terms of disease specificity.

\section{Hong Kong Med J 2018;24:261-9}

DOI: 10.12809/hkmj177007

\section{${ }^{1}$ EYL Au *, MB, BS, FHKAM (Pathology) \\ ${ }^{1}$ WK Ip, PhD \\ ${ }^{2}$ CS Lau, MB, ChB, FHKAM (Medicine)}

${ }^{1}$ YT Chan, MB, BS, FHKAM (Pathology)

Division of Clinical Immunology, Department of Pathology, Queen Mary Hospital, Pokfulam, Hong Kong

${ }^{2}$ Division of Rheumatology and Clinical Immunology, Department of Medicine, The University of Hong Kong, Pokfulam, Hong Kong

* Corresponding author: elaineauyl@gmail.com

New knowledge added by this study

- The sensitivity of the BioPlex 2200 ANA Screen was comparable to that of indirect immunofluorescence.

- The BioPlex 2200 multiplex platform has a comparable performance to the enzyme-linked immunosorbent assay in the detection of antibodies to specific extractable nuclear antigens, but it is less specific than conventional gel precipitation (countercurrent immunoelectrophoresis).

Implications for clinical practice or policy

- The performance of newer multiplex platforms for autoantibody detection may be different from that of conventional methods, and disease specificity of autoantibodies may change according to the test method.

- This variation may have a significant impact on the interpretation of results and on patient management.

\section{Introduction}

Connective tissue disease is a group of disorders characterised by the presence of antinuclear antibodies (ANAs) and clinical autoimmune phenomena. The investigations that are performed depend on both purpose and performance characteristics. For example, to rule out a diagnosis, a test with high sensitivity is needed, such as testing for the absence of ANAs to rule out systemic lupus erythematosus (SLE). In contrast, to establish a diagnosis, a test with high specificity is more desirable, such as testing for antibodies to doublestranded DNA (dsDNA) or anti-Sm antigens in SLE. Therefore, after an initial positive ANA test result, subsequent tests for specific antibodies, such as those against dsDNA and certain extractable nuclear antigens (ENAs), are necessary.

Conventionally, ANAs are detected by indirect 


\section{對於多重流式免疫測定技術與常規性測定技術在 偵測系統性紅斑狼瘕病人中的自身抗體上的評鑑 \\ 區婉寧、葉偉基、劉澤星、陳育達}

引言：常規性診斷測定技術正逐漸被多重流式自動免疫測定技術所取 代, 然而這兩項技術的效能需要評鑑。我們把多重流式免疫測定技 術與常規性測定技術在偵測系統性紅斑狼瘡病人血清中的抗核抗體 (ANA) 和特定可提取核抗原抗體（ENA）比作較

方法：納入140名華籍系統性紅斑狼瘡患者和 41 名健康對照者參與研 究。本研究將Bio-Rad Laboratories生產的BioPlex 2200 ANA篩選測定 法與間接免疫熒光法進行比較。此外, BioPlex 2200檢測抗ENA也會 與對流免疫電泳（CIEP）、酶聯免疫吸附測定（ELISA）和線性印蹟 的內部測定進行比較。

結果：BioPlex檢測ANA的靈敏度和特異性（分別為91.4\%和95.1\%) 與間接免疫焱光法（分別為 $90.7 \%$ 和 $85.4 \%$ ) 相當。總體而 言, BioPlex與ELISA檢測抗ENA方面達到最佳一致性：對於大多 數抗體類型, 一致性超過 $90 \%(\kappa=0.79-0.94)$ 。相反, BioPlex與 CIEP的一致性最差, 從抗Sm抗體的 $85.6 \%(\mathrm{k}=0.33)$ 到抗Ro抗體的 93.9\%（ $\kappa=0.88 ） 。$ 綜合以上, BioPlex和ELISA具最高靈敏度, 而 CIEP具最高特異性。在疾病相關性方面, CIEP檢測到的抗 $S m$ 對狼瘡 性腎炎具有最佳陽性預測值和特異性。

結論：這項本地研究顯示BioPlex在檢測ANA時, 表現與間接免疫焱光 法的靈敏度相若; 在檢測抗ENA方面也與ELISA表現相當。然而, 就 疾病特異性而言, CIEP卻是最好的方法。 immunofluorescence (IIF). This method is sensitive and essentially detects all antibodies against cellular constituents, with antibody profile having varying clinical significance. However, it is labour-intensive, and technical interpretation of the results can be subjective. The enzyme-linked immunosorbent assay (ELISA), which can be automated and highthroughput-enabled, is gaining popularity over IIF. When ELISA is used to screen for ANAs, the source of antigens has major implications on the sensitivity and specificity of the assay. Although the ELISA technique has improved with time, concerns over false-negative ANA cases persist. Therefore, the American College of Rheumatology (ACR) still recommends IIF as the gold standard in ANA testing. ${ }^{1}$

To detect antibodies against ENAs, gel precipitation assays have been used for more than five decades, and countercurrent immunoelectrophoresis (CIEP) has been accepted as the reference method for anti-ENA antibody testing. Positive results from CIEP are highly specific. The majority of the literature on autoantibodies and disease association has been established with this technique. ${ }^{2}$ However, other methods such as ELISA, immunoblot, and line blot are gradually replacing CIEP. In recent years, multiplex assays have been introduced. The BioPlex 2200 ANA Screen assay (Bio-Rad Laboratories,
Hercules [CA], US) is an automated multiplex immunoassay using flow cytometry to detect a panel of autoantibodies, including ANAs and antibodies against ENAs. There are a few published studies showing reasonable agreement between this system and ELISA..$^{3-7}$

Conventional assays are being replaced with newer automated high-throughput assays. However, the performance of the newer techniques may not be equivalent to that of conventional assays. This difference will have important implications to clinicians, who may base their clinical judgement on their knowledge of how conventional assays perform. ${ }^{8-16}$ In this study, we evaluate the performance of BioPlex 2200 using serum samples from a local cohort of SLE patients, and compare it with the performance of three established techniques (CIEP, ELISA, line blot) in terms of anti-ENA antibody detection. The sensitivity of BioPlex 2200 ANA Screen assay was also compared with IIF.

\section{Methods}

\section{Study setting and participant recruitment}

This cross-sectional study was conducted at the Queen Mary Hospital, Hong Kong, a tertiary university teaching hospital. Patients were recruited from the hospital's lupus clinic from 1 December 2013 to 31 December 2013. All patients attending the clinic underwent routine serology screening during their visit. Of 160 consecutive patients, 140 with adequate serum stored in the clinical immunology laboratory were recruited. All patients had an established diagnosis of SLE, according to the ACR classification criteria. ${ }^{17}$ Patients who were $<18$ years or $>80$ years and pregnant patients were excluded from the study. Data of serum samples in 41 healthy controls, who were mainly laboratory staff and had given verbal consent for the blood donation were also included; their age ranged from 18 to 54 years. All stocked serum was stored at $-70^{\circ} \mathrm{C}$.

\section{Assessment of clinical variables}

Electronic and written medical records of the recruited patients were reviewed, and relevant clinical and laboratory data were collected. Global disease activity was assessed according to the SLE disease activity index, ${ }^{18,19}$ and cumulative organ damage was assessed in terms of the Systemic Lupus International Collaborating Clinics/ACR Damage Index score. ${ }^{20}$

\section{Antinuclear antibody detection}

\section{BioPlex 2200 automated system}

The BioPlex 2200 ANA Screen system was used to detect 13 types of autoantibodies simultaneously in one test-namely, those against dsDNA, chromatin, 
centromere B, Scl-70, RNP (RNP-A, RNP-68), Sm, RNP/Sm, Ro (SSA-52, SSA-60), SSB/La, Jo-1, and ribosomal $\mathrm{P}$ protein. For BioPlex results, anti-RNP was reported separately from anti-RNP/Sm; the kit's RNP antigen is a recombinant antigen (RNP-A and RNP-68) whereas RNP/Sm is an affinity-purified antigen, which is similar to the antigen used for the RNP test in ELISA and line blot in this study.

The presence of anti-dsDNA antibody was classified as negative if levels were $\leq 4 \mathrm{IU} / \mathrm{mL}$, indeterminate if 5 to $9 \mathrm{IU} / \mathrm{mL}$, and positive if $\geq 10 \mathrm{IU} / \mathrm{mL}$, as recommended by the manufacturer. For the other autoantibodies, the results were expressed as an antibody index (AI). An AI of 1.0 was the cut-off concentration that corresponded to approximately the 99th percentile of values obtained from a nondiseased population in the manufacturer's study. Results of $\geq 1.0$ were reported as positive (range, 0.2-8.0 AI). A test result was considered positive for ANAs if one or more of the antibody tests in the panel was positive.

\section{Indirect immunofluorescence}

The IIF assay was adopted as the reference method for ANA detection. All serum samples were diluted in 1:80 in phosphate-buffered saline and tested on slides pretreated with substrate from a human epithelial cell line (Kallestad HEp-2 Cell Line Substrate Slides; Bio-Rad Laboratories, Hercules [CA], US) according to the manufacturer's instructions. The slides were read using the same microscope and setting as routine clinical samples by a single observer. Slides that were negative for ANA by IIF were reviewed by an independent second observer to confirm negativity. In cases of discrepancy, a third adjudicator was sought.

\section{Anti-extractable nuclear antigen antibody detection}

The performance of BioPlex in the detection of anti-ENA antibodies was compared with that of the following assays.

\section{Countercurrent immunoelectrophoresis}

The CIEP assay used in this study was optimised inhouse. Rabbit thymus extract (ImmunoVision Inc, United States) was used for typing of anti-Sm, antiRNP, and anti-La, whereas human spleen extract (ImmunoVision Inc) was used as a source of Ro antigen.

\section{Line blot}

The EUROASSAY test kit (EUROIMMUN, Lübeck, Germany) was used as the line blot immunoassay in this study. The kit qualitatively assessed the presence of human immunoglobulin G (IgG) autoantibodies against six different antigens: RNP, Sm, SS-A, SS-B,
$\mathrm{SCl}-70$, and Jo-1. On the basis of signal intensity, the results were categorised as negative, borderline, and positive.

\section{Enzyme-linked immunosorbent assay}

The QUANTA Lite ENA Profile EIA kit (INOVA Diagnostics, San Diego [CA], US) was used for ELISA in this study. The kit qualitatively screened for the presence of IgG autoantibodies against specific ENAs - namely, SSA (60 and $52 \mathrm{kDa}$ ), SSB, Sm, RNP/ Sm, Scl-70, and Jo-1. The results were calculated using the following formula (where OD = optical density at $450 \mathrm{~nm}$ ):

Sample/positive control OD Cut-off control OD $\times 10=$ sample/control value $(U / m L)$

Results of $<8 \mathrm{U} / \mathrm{mL}$ were classified as negative, 8 to $12 \mathrm{U} / \mathrm{mL}$ as equivocal, and $>12 \mathrm{U} / \mathrm{mL}$ as positive.

\section{Statistical analysis}

The diagnostic performance of BioPlex versus that of IIF was compared for the detection of ANAs in the SLE cohort and controls. Assay sensitivity and specificity were calculated and compared using a paired McNemar's test. Cohen's kappa coefficient and percentage of observed agreement were also calculated for the two methods.

For individual anti-ENA antibodies (against RNP, Sm, Ro, La, Scl-70, and Jo-1), agreement analysis was calculated for the four laboratory methods. Fleiss' kappa coefficient with its 95\% confidence interval and the percentage of observed agreement were calculated to assess overall agreement among the four methods. Pairwise agreement analysis for the four methods was also performed by calculating Cohen's kappa coefficient and percentage of observed agreement. Weak and borderline results in the ELISA and line blots were treated as negative in the analysis.

The diagnostic value of anti-ENA antibody detection to predict various disease manifestations was examined, along with comparisons between the different methods. In particular, we studied diagnostic performance for the association of anti-Sm antibodies with nephritis, anti-RNP antibodies with Raynaud's phenomenon, and anti-Ro/La antibodies with photosensitivity, discoid rash, Sicca symptoms, leukopenia, and lymphopenia. ${ }^{21-26}$ Sensitivity, specificity, positive and negative predictive values, and diagnostic accuracies were calculated.

The SPSS (Windows version 20.0; IBM Corp, Armonk [NY], US) and Microsoft Excel 2010 for Windows were used for statistical analysis and calculation of confidence intervals, respectively. $P$ values of $<0.05$ were regarded as statistical significance. The STARD 2015 guidelines were used during the writing of this article. ${ }^{27}$ 


\section{Results}

\section{Patients and autoantibodies}

All 140 SLE patients were local Chinese patients, with a female predominance $(\mathrm{n}=128,91.4 \%)$. The mean age was 46.8 (range, 24-69) years and the median disease duration was 17 years (Table 1). The majority of our cohort had at least one antiENA antibody present $(\mathrm{n}=114,81.4 \%)$ as detected by the BioPlex method (Table 2). Anti-Ro antibody was the most commonly detected antibody, ranging from $50.7 \%$ to $62.9 \%$ of the cohort depending on the assay method (Table 2). Methods other than CIEP had a positivity rate of $1.4 \%$ to $5.0 \%$ for anti-Scl-70 antibody and $0.7 \%$ to $2.1 \%$ for anti-Jo- 1 antibody.

\section{BioPlex antinuclear antibody screen versus indirect immunofluorescence}

The sensitivity of the BioPlex 2200 ANA Screen assay in the SLE cohort was $91.4 \%$, which was comparable to that of IIF (90.7\%; Table 3). The specificity of BioPlex among healthy controls was high, reaching $95.1 \%$, compared with $85.4 \%$ for IIF, although the difference was not statistically significant. The agreement between BioPlex and IIF was moderate $(\kappa=0.657)$. Eight patients tested positive by IIF, but negative by BioPlex. The IIF patterns of these cases were either weak homogeneous or weak finespeckled. Nine patients were negative by IIF, but positive by BioPlex; these included two with a low titre of anti-dsDNA antibodies, one with anti-Sm antibodies, one with anti-RNP antibodies, and five with anti-Ro antibodies. Four patients tested ANA-negative by both methods; all four had a longstanding history of SLE (12-40 years). All had had severe disease manifestations, including cerebral lupus and lupus nephritis, and all had been taking powerful immunosuppressants for years, although the disease had become stable and inactive in recent years. Interestingly, they had been ANA-positive in the past. Possible changes in their serology after a long period of heavy immunosuppression for disease control may have accounted for the observed results.

\section{Agreement between assays for antibodies to extractable nuclear antigens}

In terms of agreement between different methods, BioPlex achieved the best agreement with ELISA, of $>90 \%$ for the detection of most of the antibodies tested by ELISA (Table 4). The agreement between

TABLE I. Baseline characteristics of participants

\begin{tabular}{|c|c|c|c|}
\hline & SLE patients $(n=140)$ & Controls $(n=41)$ & Overall $(n=181)$ \\
\hline Age, mean (SD), y & $46.8(11.3)$ & 35.5 (13.3) & $45.2(12.2)$ \\
\hline Female, No. (\%) & $128(91.4)$ & $23(56)$ & $151(83.4)$ \\
\hline Disease duration, median (IQR), y & $17(12.3)$ & - & - \\
\hline Rheumatic manifestation, No. (\%) & & - & - \\
\hline Photosensitivity & $118(84.3)$ & & \\
\hline Malar rash & $106(75.7)$ & & \\
\hline Discoid rash & $14(10.0)$ & & \\
\hline Oral ulcers & $21(15.0)$ & & \\
\hline Arthritis & $91(65.0)$ & & \\
\hline Serositis & $19(13.6)$ & & \\
\hline Nephritis & $94(67.1)$ & & \\
\hline Class II/III & $21(15.0)$ & & \\
\hline Class IV & $42(30.0)$ & & \\
\hline Class V & $31(22.1)$ & & \\
\hline Neurological & $34(24.3)$ & & \\
\hline Haematological & $96(68.6)$ & & \\
\hline AlHA & $23(16.4)$ & & \\
\hline AITP & 27 (19.3) & & \\
\hline Leukopenia & $53(37.9)$ & & \\
\hline Lymphopenia & $76(54.3)$ & & \\
\hline Sicca symptoms & $37(26.4)$ & & \\
\hline Raynaud's phenomenon & $33(23.6)$ & & \\
\hline
\end{tabular}

Abbreviations: AlHA = autoimmune haemolytic anaemia; AITP = autoimmune thrombocytopenia purpura; IQR = interquartile range; $\mathrm{SD}=$ standard deviation; SLE = systemic lupus erythematosus 
TABLE 2. Detection of anti-ENA antibodies for SLE patients and controls, by assay method*

\begin{tabular}{|c|c|c|c|c|c|}
\hline & ENA & CIEP & ELISA & Line blotł & BioPlex \\
\hline \multirow[t]{8}{*}{ SLE } & RNP & 27 (19.3) & $49(35.0)$ & $36(25.7)$ & $\begin{array}{c}\text { RNP: } 55 \text { (39.3) } \\
\text { RNP/Sm: } 53(37.9)\end{array}$ \\
\hline & $\mathrm{Sm}$ & $8(5.7)$ & $28(20.0)$ & $11(7.9)$ & $34(24.3)$ \\
\hline & Ro & 83 (59.3) & $85(60.7)$ & $71(50.7)$ & 88 (62.9) \\
\hline & $\mathrm{La}$ & $20(14.3)$ & $40(28.6)$ & $22(15.7)$ & $37(26.4)$ \\
\hline & Scl-70 & - & $3(2.1)$ & $2(1.4)$ & $7(5.0)$ \\
\hline & Jo-1 & - & $3(2.1)$ & $1(0.7)$ & $1(0.7)$ \\
\hline & Others & $7(5.0)$ & - & - & - \\
\hline & Any ENA & $96(68.6)$ & 107 (76.4) & $94(67.1)$ & $114(81.4)$ \\
\hline \multirow[t]{8}{*}{ Controls } & RNP & 0 & 0 & 0 & $\begin{array}{l}\text { RNP: } 0 \\
\text { RNP/Sm: } 0\end{array}$ \\
\hline & $\mathrm{Sm}$ & 0 & $1(2.4)$ & 0 & 0 \\
\hline & Ro & 0 & 0 & 0 & 0 \\
\hline & $\mathrm{La}$ & 0 & 0 & 0 & $1(2.4)$ \\
\hline & Scl-70 & - & 0 & 0 & $1(2.4)$ \\
\hline & Jo-1 & - & 0 & 0 & 0 \\
\hline & Others & 0 & - & - & - \\
\hline & Any ENA & 0 & $1(2.4)$ & 0 & $2(4.9)$ \\
\hline
\end{tabular}

Abbreviations: CIEP = countercurrent immunoelectrophoresis; ELISA = enzyme-linked immunosorbent assay; ENA = extractable nuclear antigen; SLE = systemic lupus erythematosus

* Data are shown as No. (\%)

$\dagger$ Precipitation band with undefined specificity

$\ddagger$ Weak borderline results were counted as negative

TABLE 3. Diagnostic accuracy of antinuclear antibody test by BioPlex versus indirect immunofluorescence as reference

\begin{tabular}{|c|c|c|c|c|c|}
\hline & \multicolumn{2}{|c|}{ BioPlex } & \multicolumn{2}{|c|}{ Immunofluorescence } & \multirow[t]{2}{*}{ P value* } \\
\hline & + & - & + & - & \\
\hline SLE & $128 / 140$ & $12 / 140$ & $127 / 140$ & $13 / 140$ & \\
\hline Controls & $2 / 41$ & $39 / 41$ & $6 / 41$ & $35 / 41$ & \\
\hline Sensitivity $(95 \% \mathrm{Cl}), \%$ & \multicolumn{2}{|c|}{$91.4(85.2-95.3)$} & \multicolumn{2}{|c|}{$90.7(84.3-94.8)$} & 0.815 \\
\hline Specificity (95\% Cl), \% & \multicolumn{2}{|c|}{$95.1(82.2-99.2)$} & \multicolumn{2}{|c|}{$85.4(70.1-93.9)$} & 0.219 \\
\hline Agreement between methods $(95 \% \mathrm{Cl})$ & \multicolumn{4}{|c|}{$\begin{array}{c}\text { Cohen's kappa }=0.657(0.532-0.782) \\
\text { Agreement }=86.2 \%\end{array}$} & \\
\hline
\end{tabular}

Abbreviations: $\mathrm{Cl}=$ confidence interval; SLE = systemic lupus erythematosus

* McNemar's test

BioPlex and ELISA was $95.6 \%$ for anti-RNP/Sm in detecting autoantibodies in the SLE cohort than antibodies $(\kappa=0.89), 93.9 \%$ for anti-Sm $(\kappa=0.79)$, the other two methods (Table 2). There were a few $97.2 \%$ for anti-Ro $(\kappa=0.94)$, and $95.6 \%$ for anti-La positive cases of anti-Scl-70 and anti-Jo-1 antibody $(\kappa=0.87)$. In contrast, the agreement between BioPlex detection in the cohort by all assays except CIEP, and CIEP was not as strong. Agreement was $84.5 \%$ although the clinical significance of these antibodies for detection of anti-RNP antibodies ( $k=0.57), 85.6 \%$ for anti-Sm ( $\kappa=0.33), 93.9 \%$ for anti-Ro $(\kappa=0.88)$, and $89.0 \%$ for anti-La $(\kappa=0.6)$. Overall, the CIEP tended to agree better with the line blot assay than with ELISA or BioPlex.

\section{Performance of assays for antibodies to extractable nuclear antigens}

in patients with SLE is uncertain.

In the healthy control group, CIEP had the highest specificity; none of the healthy subjects had anti-ENA autoantibodies when tested by CIEP (Table 2). With BioPlex, however, 2.4\% (1/41) of the controls for each were positive for anti-La and anti-Scl-70 antibodies. For the line blot, if a weak borderline band were considered positive, then Overall, BioPlex and ELISA had a higher sensitivity $4.9 \%$ (2/41) of the subjects were positive for anti-La 
antibodies (data not shown). If a weak borderline band were considered negative, then none of the healthy controls tested positive. For ELISA, if borderline results were counted negative then $2.4 \%$ $(1 / 41)$ of the healthy controls still tested positive for anti-Sm antibodies.

\section{Antibodies to extractable nuclear antigens and disease manifestations}

Among the panel of anti-ENA autoantibodies tested, anti-Sm antibody had the best predictive value for the presence of lupus nephritis. However, the predictive value was method-dependent (Table 5). Anti-Sm antibody detection by CIEP had the best positive predictive value for lupus nephritis, reaching $87.5 \%$. The specificity of anti-Sm antibody detection by CIEP for lupus nephritis was high, reaching 98.6\%, although the sensitivity was only $10.4 \%$. Anti-Sm antibody detection by BioPlex in nephritis had a higher sensitivity of $26.9 \%$, however, the specificity and positive predictive value were lower than those achieved by CIEP (78.1\% and 52.9\%, respectively).

Anti-RNP antibody detection by CIEP had a specificity of $84.1 \%$ for Raynaud's phenomenon, whereas the specificity by other methods was lower $(69.2 \%$ for ELISA, $78.5 \%$ for line blot, and

TABLE 4. Agreement between four assay methods to detect anti-ENA antibodies

\begin{tabular}{|c|c|c|c|c|c|c|c|c|c|c|c|c|c|c|}
\hline \multirow[t]{2}{*}{ ENA } & \multirow{2}{*}{$\begin{array}{c}\text { Overall } \\
\text { kappa† } \\
(95 \% \mathrm{Cl})\end{array}$} & \multirow{2}{*}{$\begin{array}{c}\text { Overall } \\
\text { agree, } \\
\%\end{array}$} & \multicolumn{2}{|c|}{ BioPlex vs CIEP } & \multicolumn{2}{|c|}{ BioPlex vs ELISA } & \multicolumn{2}{|c|}{$\begin{array}{c}\text { BioPlex vs line } \\
\text { blot }\end{array}$} & \multicolumn{2}{|c|}{ ELISA vs CIEP } & \multicolumn{2}{|c|}{ ELISA vs line blot } & \multicolumn{2}{|c|}{ Line blot vs CIEP } \\
\hline & & & $\begin{array}{l}\text { Kappał } \\
(95 \% \text { Cl) }\end{array}$ & $\begin{array}{c}\text { Agree, } \\
\%\end{array}$ & $\begin{array}{l}\text { Kappał } \\
\text { (95\% Cl) }\end{array}$ & $\begin{array}{c}\text { Agree, } \\
\%\end{array}$ & $\begin{array}{l}\text { Kappał } \\
\text { (95\% Cl) }\end{array}$ & $\begin{array}{c}\text { Agree, } \\
\%\end{array}$ & $\begin{array}{l}\text { Kappał } \\
\text { (95\% Cl) }\end{array}$ & $\begin{array}{c}\text { Agree, } \\
\%\end{array}$ & $\begin{array}{l}\text { Kappał } \\
\text { (95\% Cl) }\end{array}$ & $\begin{array}{c}\text { Agree, } \\
\%\end{array}$ & $\begin{array}{l}\text { Kappał } \\
\text { (95\% Cl) }\end{array}$ & $\begin{array}{c}\text { Agree, } \\
\%\end{array}$ \\
\hline Sm & $\begin{array}{c}0.50 \\
(0.44-0.56)\end{array}$ & 82.9 & $\begin{array}{c}0.33 \\
(0.09-0.57)\end{array}$ & 85.6 & $\begin{array}{c}0.79 \\
(0.67-0.91)\end{array}$ & 93.9 & $\begin{array}{c}0.34 \\
(0.11-0.57)\end{array}$ & 85.1 & $\begin{array}{c}0.39 \\
(0.14-0.64)\end{array}$ & 88.4 & $\begin{array}{c}0.51 \\
(0.29-0.73)\end{array}$ & 90.1 & $\begin{array}{c}0.61 \\
(0.33-0.89)\end{array}$ & 96.1 \\
\hline Ro & $\begin{array}{c}0.85 \\
(0.79-0.91)\end{array}$ & 86.7 & $\begin{array}{c}0.88 \\
(0.81-0.95)\end{array}$ & 93.9 & $\begin{array}{c}0.94 \\
(0.89-0.99)\end{array}$ & 97.2 & $\begin{array}{c}0.79 \\
(0.70-0.88)\end{array}$ & 89.5 & $\begin{array}{c}0.89 \\
(0.82-0.96)\end{array}$ & 94.5 & $\begin{array}{c}0.82 \\
(0.74-0.90)\end{array}$ & 91.2 & $\begin{array}{c}0.80 \\
(0.71-0.89)\end{array}$ & 90.1 \\
\hline $\mathrm{La}$ & $\begin{array}{c}0.67 \\
(0.61-0.73)\end{array}$ & 84.0 & $\begin{array}{c}0.6 \\
(0.43-0.77)\end{array}$ & 89.0 & $\begin{array}{c}0.87 \\
(0.78-0.96)\end{array}$ & 95.6 & $\begin{array}{c}0.65 \\
(0.49-0.81)\end{array}$ & 90.1 & $\begin{array}{c}0.57 \\
(0.40-0.74)\end{array}$ & 87.8 & $\begin{array}{c}0.62 \\
(0.46-0.78)\end{array}$ & 89.0 & $\begin{array}{c}0.68 \\
(0.5-0.86)\end{array}$ & 93.4 \\
\hline Any ENA & $\begin{array}{c}0.86 \\
(0.80-0.92)\end{array}$ & 86.7 & $\begin{array}{c}0.73 \\
(0.63-0.83)\end{array}$ & 86.7 & $\begin{array}{c}0.88 \\
(0.81-0.95)\end{array}$ & 94.5 & $\begin{array}{c}0.75 \\
(0.65-0.85)\end{array}$ & 87.8 & $\begin{array}{c}0.82 \\
(0.74-0.9)\end{array}$ & 91.2 & $\begin{array}{c}0.84 \\
(0.76-0.92)\end{array}$ & 92.3 & $\begin{array}{c}0.84 \\
(0.76-0.92)\end{array}$ & 92.3 \\
\hline $\begin{array}{l}\text { BioPlex } \\
\text { RNP/Sm }\end{array}$ & - & - & $\begin{array}{c}0.59 \\
(0.45-0.73)\end{array}$ & 85.6 & $\begin{array}{c}0.89 \\
(0.82-0.96)\end{array}$ & 95.6 & $\begin{array}{c}0.72 \\
(0.60-0.84)\end{array}$ & 89.5 & - & - & - & - & - & - \\
\hline $\begin{array}{l}\text { BioPlex } \\
\text { RNP }\end{array}$ & - & - & $\begin{array}{c}0.57 \\
(0.43-0.72)\end{array}$ & 84.5 & $\begin{array}{c}0.65 \\
(0.52-0.77)\end{array}$ & 85.5 & $\begin{array}{c}0.69 \\
(0.56-0.82)\end{array}$ & 88.1 & - & - & - & - & - & - \\
\hline
\end{tabular}

Abbreviations: CIEP = countercurrent immunoelectrophoresis; ELISA = enzyme-linked immunosorbent assay; ENA = extractable nuclear antigen

† Fleiss' kappa

‡ Cohen's kappa

TABLE 5. Diagnostic performance of predicting clinical manifestations of SLE by detection of anti-ENA antibodies, according to assay method*

\begin{tabular}{|c|c|c|c|c|c|c|c|c|}
\hline & \multicolumn{4}{|c|}{ CIEP } & \multicolumn{4}{|c|}{ ELISA } \\
\hline & Sn $(95 \% \mathrm{Cl})$ & Sp $(95 \% \mathrm{Cl})$ & PPV (95\% Cl) & NPV $(95 \% \mathrm{Cl})$ & Sn $(95 \% \mathrm{Cl})$ & Sp (95\% Cl) & PPV (95\% Cl) & NPV $(95 \% \mathrm{Cl})$ \\
\hline Nephritis vs Sm & $\begin{array}{c}10.4 \\
(3.1-17.8)\end{array}$ & $\begin{array}{c}98.6 \\
(96-100)\end{array}$ & $\begin{array}{c}87.5 \\
(64.6-100)\end{array}$ & $\begin{array}{c}54.5 \\
(46.1-63.0)\end{array}$ & $\begin{array}{c}22.4 \\
(12.4-32.4)\end{array}$ & $\begin{array}{c}82.2 \\
(73.4-91.0)\end{array}$ & $\begin{array}{c}53.6 \\
(35.1-72.0)\end{array}$ & $\begin{array}{c}53.6 \\
(44.3-62.8)\end{array}$ \\
\hline $\begin{array}{l}\text { Photosensitivity vs } \\
\text { Ro/La }\end{array}$ & $\begin{array}{c}57.6 \\
(48.7-66.5)\end{array}$ & $\begin{array}{c}27.3 \\
(8.7-45.9)\end{array}$ & $\begin{array}{c}81 \\
(72.6-89.3)\end{array}$ & $\begin{array}{c}10.7 \\
(2.6-18.8)\end{array}$ & $\begin{array}{c}59.3 \\
(50.5-68.2)\end{array}$ & $\begin{array}{c}18.2 \\
(2.1-34.3)\end{array}$ & $\begin{array}{c}79.5 \\
(71.1-88.0)\end{array}$ & $\begin{array}{c}7.7 \\
(0.4-14.9)\end{array}$ \\
\hline $\begin{array}{l}\text { Discoid rash vs } \\
\text { Ro/La }\end{array}$ & $\begin{array}{c}42.9 \\
(16.9-68.8)\end{array}$ & $\begin{array}{c}38.1 \\
(29.6-46.6)\end{array}$ & $\begin{array}{c}7.1 \\
(76.5-94.9)\end{array}$ & $\begin{array}{c}42.9 \\
(16.9-68.8)\end{array}$ & $\begin{array}{c}34.9 \\
(26.6-43.2)\end{array}$ & $\begin{array}{c}6.8 \\
(1.6-12.1)\end{array}$ & $\begin{array}{c}84.6 \\
(74.8-94.4)\end{array}$ & $\begin{array}{l}28.6 \\
(4.9-52.2)\end{array}$ \\
\hline Sicca vs Ro/La & $\begin{array}{c}75.7 \\
(61.9-89.5)\end{array}$ & $\begin{array}{c}45.6 \\
(36.0-55.3)\end{array}$ & $\begin{array}{c}33.3 \\
(23.3-43.4)\end{array}$ & $\begin{array}{c}83.9 \\
(74.3-93.5)\end{array}$ & $\begin{array}{c}81.1 \\
(68.5-93.7)\end{array}$ & $\begin{array}{c}43.7 \\
(34.1-53.3)\end{array}$ & $\begin{array}{c}34.1 \\
(24.2-44.0)\end{array}$ & $\begin{array}{c}86.5 \\
(77.3-95.8)\end{array}$ \\
\hline $\begin{array}{l}\text { Raynaud vs RNP/ } \\
\text { Sm }\end{array}$ & $\begin{array}{c}30.3 \\
(14.6-46.0)\end{array}$ & $\begin{array}{c}84.1 \\
(77.2-91.0)\end{array}$ & $\begin{array}{c}37 \\
(18.8-55.3)\end{array}$ & $\begin{array}{c}79.6 \\
(72.2-87.1)\end{array}$ & $\begin{array}{c}48.5 \\
(31.4-65.5)\end{array}$ & $\begin{array}{c}69.2 \\
(60.4-77.9)\end{array}$ & $\begin{array}{c}32.7 \\
(19.5-45.8)\end{array}$ & $\begin{array}{c}81.3 \\
(73.3-89.3)\end{array}$ \\
\hline \multicolumn{9}{|l|}{ Raynaud vs RNP } \\
\hline $\begin{array}{l}\text { Leukopenia vs } \\
\text { Ro/La }\end{array}$ & $\begin{array}{c}67.9 \\
(55.4-80.5)\end{array}$ & $\begin{array}{c}44.8 \\
(34.4-55.3)\end{array}$ & $\begin{array}{c}42.9 \\
(32.3-53.4)\end{array}$ & $\begin{array}{c}69.6 \\
(57.6-81.7)\end{array}$ & $\begin{array}{c}67.9 \\
(55.4-80.5)\end{array}$ & $\begin{array}{c}40.2 \\
(29.9-50.5)\end{array}$ & $\begin{array}{c}40.9 \\
(30.6-51.2)\end{array}$ & $\begin{array}{c}67.3 \\
(54.6-80.1)\end{array}$ \\
\hline $\begin{array}{l}\text { Lymphopenia vs } \\
\text { Ro/La }\end{array}$ & $\begin{array}{c}64.5 \\
(53.7-75.2)\end{array}$ & $\begin{array}{c}45.3 \\
(33.1-57.5)\end{array}$ & $\begin{array}{c}58.3 \\
(47.8-68.9)\end{array}$ & $\begin{array}{c}51.8 \\
(38.7-64.9)\end{array}$ & $\begin{array}{c}68.4 \\
(58.0-78.9)\end{array}$ & $\begin{array}{c}43.8 \\
(31.6-55.9)\end{array}$ & $\begin{array}{c}59.1 \\
(48.8-69.4)\end{array}$ & $\begin{array}{c}53.8 \\
(40.3-67.4)\end{array}$ \\
\hline
\end{tabular}

Abbreviations: $\mathrm{Cl}=$ confidence interval; CIEP = countercurrent immunoelectrophoresis; ELISA = enzyme-linked immunosorbent assay; ENA = extractable nuclear antigen; NPV = negative predictive value; PPV = positive predictive value; SLE = systemic lupus erythematosus; $\mathrm{Sn}=$ sensitivity; $\mathrm{Sp}=$ specificity

* Data are shown as \% 
$65.4 \%$ for BioPlex). As the prevalence of Raynaud's phenomenon in the cohort was not high, the positive predictive value was at best $37.0 \%$ only, by CIEP.

BioPlex generally had a higher sensitivity than the other methods, with the trade-off of lower specificity. However, CIEP generally performed better than BioPlex in disease-antibody associations (Table 6). The superiority of CIEP over BioPlex was most obvious in the diagnostic accuracy of linking anti-RNP antibody detection to Raynaud's phenomenon $(71.4 \%$ for CIEP vs $62.9 \%$ for BioPlex; $\mathrm{P}<0.001)$. Detection of antibodies to RNP (recombinant) and RNP/Sm by BioPlex did not differ significantly in diagnostic accuracy for association with Raynaud's phenomenon.

\section{Discussion}

In recent years, the multiplex method has been introduced in ANA testing. However, on the basis of the existing literature, this method is considered suboptimal in sensitivity compared with IIF, and its false-negative rate is similar to that of ELISA, ranging from $0.2 \%$ to $41.5 \%$ in the different populations studied. ${ }^{4,728-30}$ When Tozzoli et al ${ }^{31}$ compared the detection of ANAs between IIF using a 1:80 cut-off and BioPlex 2200 ANA Screen in a cohort of 95 SLE patients, they found that IIF had superior sensitivity over BioPlex (85/95 [89.5\%] positive vs 77/95 [81.1\%] positive, respectively). Generally, multiplex methods are considered to be simple to operate, have potential for automated and high-throughput processing, and can detect multiple specific antibodies simultaneously. Nonetheless, the main limitation is that such methods do not detect all the autoantibodies that can be detected by IIF. Hence, multiplex systems are considered to be insufficient in sensitivity and negative predictive value, and IIF remains the reference method of ANA testing. ${ }^{32,33}$

For our cohort, the BioPlex system demonstrated good sensitivity (91.4\%), comparable to that of IIF (90.7\%), with an agreement of $86.2 \%(\kappa=0.657)$. The specificity of BioPlex was slightly higher than that of IIF (95.1\% vs $85.4 \%)$ but the difference did not reach statistical significance, perhaps because of the relatively small control group. Notably, a large proportion (6 of 9 cases) of the BioPlex-positive IIF-negative cases were actually positive for anti-Ro antibodies. Although IIF is the preferred method for ANA screening, as recommended by the ACR and the European Autoimmunity Standardisation Initiative, inconsistency among IIF assays exists. ${ }^{33}$ Slides from different vendors vary in sensitivity, especially for anti-SSA/Ro antibody detection. ${ }^{34}$ Moreover, the reading and interpretation of slides are reader- and skill-dependent.

Overall, BioPlex as used in our study showed a higher performance when compared with other studies. This difference could be due to different cohort characteristics, disease activities, and ethnicities. For example, the vast majority of the literature reports on studies of Caucasian populations, and studies of Chinese populations are scarce. In addition, we recruited only patients with SLE, but not other autoimmune diseases, thereby precluding direct comparisons. We also had a relatively small number of SLE cases; hence, some ANA staining patterns (eg, nuclear dots, proliferating cell nuclear antigen, nuclear lamina)

\begin{tabular}{|c|c|c|c|c|c|c|c|}
\hline \multicolumn{4}{|c|}{ Line blot } & \multicolumn{4}{|c|}{ BioPlex } \\
\hline Sn $(95 \% \mathrm{Cl})$ & Sp $(95 \% \mathrm{Cl})$ & PPV (95\% Cl) & NPV $(95 \% \mathrm{Cl})$ & Sn $(95 \% \mathrm{Cl})$ & Sp $(95 \% \mathrm{Cl})$ & PPV $(95 \% \mathrm{Cl})$ & $\operatorname{NPV}(95 \% \mathrm{Cl})$ \\
\hline $\begin{array}{c}11.9 \\
(4.2-19.7)\end{array}$ & $\begin{array}{c}95.9 \\
(91.3-100)\end{array}$ & $\begin{array}{c}72.7 \\
(46.4-99.0)\end{array}$ & $\begin{array}{c}54.3 \\
(45.7-62.9)\end{array}$ & $\begin{array}{c}26.9 \\
(16.3-37.5)\end{array}$ & $\begin{array}{c}78.1 \\
(68.6-87.6)\end{array}$ & $\begin{array}{c}52.9 \\
(36.2-69.7)\end{array}$ & $\begin{array}{c}53.8 \\
(44.3-63.3)\end{array}$ \\
\hline $\begin{array}{c}54.2 \\
(45.2-63.2)\end{array}$ & $\begin{array}{c}40.9 \\
(20.4-61.5)\end{array}$ & $\begin{array}{c}83.1 \\
(74.7-91.5)\end{array}$ & $\begin{array}{c}14.3 \\
(5.6-22.9)\end{array}$ & $\begin{array}{c}60.2 \\
(51.3-69.0)\end{array}$ & $\begin{array}{c}18.2 \\
(2.1-34.3)\end{array}$ & $\begin{array}{c}79.8 \\
(71.4-88.1)\end{array}$ & $\begin{array}{c}7.8 \\
(0.5-15.2)\end{array}$ \\
\hline $\begin{array}{c}42.1 \\
(33.4-50.7)\end{array}$ & $\begin{array}{c}5.2 \\
(0.2-10.2)\end{array}$ & $\begin{array}{c}84.1 \\
(75.1-93.2)\end{array}$ & $\begin{array}{c}42.9 \\
(16.9-68.8)\end{array}$ & $\begin{array}{c}34.1 \\
(25.8-42.4)\end{array}$ & $\begin{array}{c}6.7 \\
(1.5-12.0)\end{array}$ & $\begin{array}{c}84.3 \\
(74.3-94.3)\end{array}$ & \\
\hline $\begin{array}{c}70.3 \\
(55.5-85.0)\end{array}$ & $\begin{array}{c}50.5 \\
(40.8-60.1)\end{array}$ & $\begin{array}{c}33.8 \\
(73.2-91.9)\end{array}$ & $\begin{array}{c}83.8 \\
(71.9-95.7)\end{array}$ & $\begin{array}{c}43.7 \\
(34.1-53.3)\end{array}$ & $\begin{array}{c}34.8 \\
(24.9-44.7)\end{array}$ & $\begin{array}{c}88.2 \\
(79.4-97.1)\end{array}$ & \\
\hline \multirow[t]{2}{*}{$\begin{array}{c}39.4 \\
(22.7-56.1)\end{array}$} & $\begin{array}{c}78.5 \\
(70.7-86.3)\end{array}$ & $\begin{array}{c}36.1 \\
(20.4-51.8)\end{array}$ & $\begin{array}{c}80.8 \\
(73.2-88.3)\end{array}$ & $\begin{array}{l}\text { RNP/Sm: } 48.5 \\
(31.4-65.5)\end{array}$ & $\begin{array}{c}\text { RNP/Sm: } 65.4 \\
(56.4-74.4)\end{array}$ & $\begin{array}{c}\text { RNP/Sm: } 30.2 \\
(17.8-42.5)\end{array}$ & $\begin{array}{c}\text { RNP/Sm: } 80.5 \\
(72.1-88.8)\end{array}$ \\
\hline & & & & $\begin{array}{l}\text { RNP: } 54.5 \\
(37.6-71.5)\end{array}$ & $\begin{array}{l}\text { RNP: } 65.4 \\
(56.4-74.4)\end{array}$ & $\begin{array}{l}\text { RNP: } 32.7 \\
(20.3-45.1)\end{array}$ & $\begin{array}{l}\text { RNP: } 82.4 \\
(74.2-90.5)\end{array}$ \\
\hline $\begin{array}{c}60.4 \\
(47.2-73.5)\end{array}$ & $\begin{array}{c}48.3 \\
(37.8-58.8)\end{array}$ & $\begin{array}{c}41.6 \\
(30.6-52.6)\end{array}$ & $\begin{array}{c}66.7 \\
(55.0-78.3)\end{array}$ & $\begin{array}{c}67.9 \\
(55.4-80.5)\end{array}$ & $\begin{array}{c}39.1 \\
(28.8-49.3)\end{array}$ & $\begin{array}{c}40.4 \\
(30.3-50.6)\end{array}$ & $\begin{array}{c}66.7 \\
(53.7-79.6)\end{array}$ \\
\hline $\begin{array}{c}57.9 \\
(46.8-69.0)\end{array}$ & $\begin{array}{c}48.4 \\
(36.2-60.7)\end{array}$ & $\begin{array}{c}57.1 \\
(46.1-68.2)\end{array}$ & $\begin{array}{c}49.2 \\
(36.9-61.6)\end{array}$ & $\begin{array}{c}67.1 \\
(56.5-77.7)\end{array}$ & $\begin{array}{c}40.6 \\
(28.6-52.7)\end{array}$ & $\begin{array}{c}57.3 \\
(47.0-67.6)\end{array}$ & $\begin{array}{c}51.0 \\
(37.3-64.7)\end{array}$ \\
\hline
\end{tabular}


TABLE 6. Diagnostic accuracy of predicting clinical manifestations of SLE by detection of anti-ENA antibodies, according to assay method*

\begin{tabular}{lccccc}
\hline & CIEP & ELISA & Line blot & BioPlex & $\begin{array}{c}\text { P value } \\
\text { (BioPlex vs CIEP)† }\end{array}$ \\
\hline Nephritis vs Sm & $56.4(48.2-64.6)$ & $53.6(45.3-61.8)$ & $55.7(47.5-63.9)$ & $53.6(45.3-61.8)$ & 0.279 \\
Photosensitivity vs Ro/La & $52.9(44.6-61.1)$ & $52.9(44.6-61.1)$ & $52.1(43.9-60.4)$ & $53.6(45.3-61.8)$ & 0.500 \\
Discoid rash vs Ro/La & $38.6(30.5-46.6)$ & $35.7(27.8-43.7)$ & $40.7(32.6-48.9)$ & $35.0(27.1-42.9)$ & 0.002 \\
Sicca vs Ro/La & $53.6(45.3-61.8)$ & $53.6(45.3-61.8)$ & $55.7(47.5-63.9)$ & $54.3(46.0-62.5)$ & 0.400 \\
Raynaud vs RNP/Sm & $71.4(63.9-78.9)$ & $64.3(56.3-72.2)$ & $69.3(61.6-76.9)$ & RNP/Sm: $61.4(53.4-69.5)$ & 0.001 \\
Raynaud vs RNP & & & & RNP: $62.9(54.9-70.9)$ & $<0.001$ \\
Leukopenia vs Ro/La & $53.6(45.3-61.8)$ & $50.7(42.4-59.0)$ & $52.9(44.6-61.1)$ & $50(41.7-58.3)$ & 0.731 \\
Lymphopenia vs Ro/La & $55.7(47.5-63.9)$ & $57.1(48.9-65.3)$ & $53.6(45.3-61.8)$ & $55(46.8-63.2)$ & 0.235 \\
\hline
\end{tabular}

Abbreviations: CIEP = countercurrent immunoelectrophoresis; ELISA = enzyme-linked immunosorbent assay; ENA = extractable nuclear antigen; SLE = systemic lupus erythematosus

* Data are shown as \% (95\% confidence interval)

+ McNemar's test

were not encountered in the cohort, which limits the evaluation. Given the available literature and international recommendations, IIF remains the preferred method for ANA test until more supportive data for BioPlex are available.

In our study, CIEP performed best in terms of specificity, with none of the healthy controls testing positive for anti-ENA antibodies. In contrast, the specificity of the other platforms, especially ELISA and BioPlex, was less optimal, and positivity for antibodies to Sm (ELISA), Scl-70 (BioPlex), and La (BioPlex) was recorded. In addition, anti-Scl-70 and anti-Jo-1 antibodies were detected in assays other than CIEP in the SLE group. If appropriate disease controls, such as vasculitis, rheumatoid arthritis, and chronic infections are included, the performance of these assays would be better characterised.

There were several important limitations in our study. First, this was a cross-sectional study, and the clinical features and manifestations were retrospectively reviewed. The reviewer of the medical records was not blinded to the results of assays, which may have led to potential bias in record review and data extraction. Second, the performance of BioPlex was not evaluated in other rheumatic or autoimmune disease groups, which limits the generalisability of the results in other settings. Third, the number of participants included, especially that of healthy controls, was relatively small; disease controls were not included; and the controls were not age- and sex- matched with cases. These limitations may have led to bias in the evaluation of anti-ENA antibody assays. Finally, autoantibodies may precede clinical manifestations for years. A prospective study with parallel assessment of cases referred to the laboratory for ANA and anti-ENA antibody assessment by different techniques, as well as follow-up of the clinical manifestations and diagnosis, may provide a better assessment of the BioPlex system.

\section{Conclusions}

The BioPlex 2200 ANA Screen demonstrated comparable sensitivity to IIF in a local SLE cohort. The detection of specific antibodies, including those against ENAs, by the BioPlex system was more sensitive than that by CIEP, although with less specificity. Overall performance of BioPlex resembled that of the conventional ELISA technique, but with higher speed and turnaround time. Hence, BioPlex can be considered as a high-throughput ELISA-like assay for the detection of anti-ENA antibodies in SLE.

\section{Author contributions}

All authors have made substantial contributions to the concept or design of this study; acquisition of data; analysis or interpretation of data; drafting of the article; and critical revision for important intellectual content.

\section{Funding/support}

This research received no specific grant from any funding agency in the public, commercial, or not-for-profit sectors.

\section{Declaration}

All authors have no conflicts of interest to disclose. All authors had full access to the data, contributed to the study, approved the final version for publication, and take responsibility for its accuracy and integrity.

\section{Ethical approval}

This study was approved by The University of Hong Kong/ Hospital Authority Hong Kong West Cluster Institutional Review Board (Ref No. UW14-442). The requirement for patient consent was waived by the ethics board.

\section{References}

1. Meroni PL, Schur PH. ANA screening: an old test with new recommendations. Ann Rheum Dis 2010;69:1420-2.

2. Clotet B, Guardia J, Pigrau $C$, et al. Incidence and clinical significance of anti-ENA antibodies 
in systemic lupus erythematosus. Estimation by counterimmunoelectrophoresis. Scand J Rheumatol 1984;13:15-20.

3. Hanly JG, Su L, Farewell V, Fritzler MJ. Comparison between multiplex assays for autoantibody detection in systemic lupus erythematosus. J Immunol Methods 2010;358:75-80.

4. Hanly JG, Thompson K, McCurdy G, Fougere L, Theriault $\mathrm{C}$, Wilton K. Measurement of autoantibodies using multiplex methodology in patients with systemic lupus erythematosus. J Immunol Methods 2010;352:147-52.

5. Kim Y, Park Y, Lee EY, Kim HS. Comparison of automated multiplexed bead-based ANA screening assay with ELISA for detecting five common anti-extractable nuclear antigens and anti-dsDNA in systemic rheumatic diseases. Clin Chim Acta 2012;413:308-11.

6. Shovman O, Gilburd B, Barzilai O, et al. Evaluation of the BioPlex 2200 ANA screen: analysis of 510 healthy subjects: incidence of natural/predictive autoantibodies. Ann N Y Acad Sci 2005;1050:380-8.

7. Desplat-Jego S, Bardin N, Larida B, Sanmarco M. Evaluation of the BioPlex 2200 ANA screen for the detection of antinuclear antibodies and comparison with conventional methods. Ann N Y Acad Sci 2007;1109:245-55.

8. Orton SM, Peace-Brewer A, Schmitz JL, Freeman K, Miller WC, Folds JD. Practical evaluation of methods for detection and specificity of autoantibodies to extractable nuclear antigens. Clin Diagn Lab Immunol 2004;11:297301.

9. Lock RJ, Unsworth DJ. Antibodies to extractable nuclear antigens. Has technological drift affected clinical interpretation? J Clin Pathol 2001;54:187-90.

10. Phan TG, Wong RC, Adelstein S. Autoantibodies to extractable nuclear antigens: making detection and interpretation more meaningful. Clin Diagn Lab Immunol 2002;9:1-7.

11. Kumar Y, Bhatia A, Minz RW. Antinuclear antibodies and their detection methods in diagnosis of connective tissue diseases: a journey revisited. Diagn Pathol 2009;4:1.

12. Emlen W, O’Neill L. Clinical significance of antinuclear antibodies: comparison of detection with immunofluorescence and enzyme-linked immunosorbent assays. Arthritis Rheum 1997;40:1612-8.

13. González C, Martin T, Arroyo T, García-Isidoro M, Navajo JA, González-Buitrago JM. Comparison and variation of different methodologies for the detection of autoantibodies to nuclear antigens (ANA). J Clin Lab Anal 1997;11:388-92.

14. Bruner BF, Guthridge JM, Lu R, et al. Comparison of autoantibody specificities between traditional and beadbased assays in a large, diverse collection of patients with systemic lupus erythematosus and family members. Arthritis Rheum 2012;64:3677-86.

15. Egner W. The use of laboratory tests in the diagnosis of SLE. J Clin Pathol 2000;53:424-32.

16. Wiik AS, Gordon TP, Kavanaugh AF, et al. Cutting edge diagnostics in rheumatology: the role of patients, clinicians, and laboratory scientists in optimizing the use of autoimmune serology. Arthritis Rheum 2004;51:291-8.

17. Tan EM, Cohen AS, Fries JF, et al. The 1982 revised criteria for the classification of systemic lupus erythematosus. Arthritis Rheum 1982;25:1271-7.

18. Petri M, Hellmann D, Hochberg M. Validity and reliability of lupus activity measures in the routine clinic setting. J Rheumatol 1992;19:53-9.

19. Urowitz MB, Gladman DD. Measures of disease activity and damage in SLE. Baillieres Clin Rheumatol 1998;12:40513.

20. Gladman D, Ginzler E, Goldsmith C, et al. The development and initial validation of the systemic lupus international collaborating clinics/American College of Rheumatology damage index for systemic lupus erythematosus. Arthritis Rheum 1996;39:363-9.

21. Tan EM, Fritzler MJ, McDougal JS, et al. Reference sera for antinuclear antibodies. I. Antibodies to native DNA, Sm, nuclear RNP, and SS-B/La. Arthritis Rheum 1982;25:10035.

22. Isenberg DA, Maddison PJ. Detection of antibodies to double stranded DNA and extractable nuclear antigen. J Clin Pathol 1987;40:1374-81.

23. McCain GA, Bell DA, Chodirker WB, Komar RR. Antibody to extractable nuclear antigen in the rheumatic diseases. J Reumatol 1978;5:399-406.

24. Hamburger M, Hodes S, Barland P. The incidence and clinical significance of antibodies to extractable nuclear antigens. Am J Med Sci 1977;273:21-8.

25. Clark G, Reichlin M, Tomasi TB Jr. Characterization of a soluble cytoplasmic antigen reactive with sera from patients with systemic lupus erythematosus. J Immunol 1969;102:117-22.

26. Tan EM, Kunkel HG. Characteristics of a soluble nuclear antigen precipitating with sera of patients with systemic lupus erythematosus. J Immunol 1966;96:464-71.

27. Bossuyt PM, Reitsma JB, Bruns DE, et al. STARD 2015: an updated list of essential items for reporting diagnostic accuracy studies. BMJ 2015;351:h5527.

28. Jaskowski TD, Schroder C, Martins TB, Mouritsen CL, Litwin CM, Hill HR. Screening for antinuclear antibodies by enzyme immunoassay. Am J Clin Pathol 1996;105:46873.

29. Damoiseaux J, Vaessen M, Knapen Y, et al. Evaluation of the FIDIS vasculitis multiplex immunoassay for diagnosis and follow-up of ANCA-associated vasculitis and Goodpasture's disease. Ann N Y Acad Sci 2007;1109:45463.

30. Bonilla E, Francis L, Allam F, et al. Immunofluorescence microscopy is superior to fluorescent beads for detection of antinuclear antibody reactivity in systemic lupus erythematosus patients. Clin Immunol 2007;124:18-21.

31. Tozzoli R, Bonaguri C, Melegari A, Antico A, Bassetti D, Bizzaro N. Current state of diagnostic technologies in the autoimmunology laboratory. Clin Chem Lab Med 2013;51:129-38.

32. Op De Beéck K, Vermeersch P, Verschueren P, et al. Antinuclear antibody detection by automated multiplex immunoassay in untreated patients at the time of diagnosis. Autoimmun Rev 2012;12:137-43.

33. Agmon-Levin N, Damoiseaux J, Kallenberg C, et al. International recommendations for the assessment of autoantibodies to cellular antigens referred to as antinuclear antibodies. Ann Rheum Dis 2014;73:17-23.

34. Copple SS, Giles SR, Jaskowski TD, Gardiner AE, Wilson AM, Hill HR. Screening for IgG antinuclear autoantibodies by HEp- 2 indirect fluorescent antibody assays and the need for standardization. Am J Clin Pathol 2012;137:825-30. 